\title{
RECONSTRUCT THE CLASS ASSESSMENT STRATEGY: PROMOTING THE 21st-CENTURY LEARNING
}

\author{
Undang Rosidin ${ }^{1}$, Novi Haryanti ${ }^{2 *}$, Haditya Aprita Lora ${ }^{3}$, Viyanti ${ }^{4}$ \\ 1,2,3,4Physics Education Master Program, Universitas Lampung, Indonesia \\ *Corresponding author: noviharyanti8283@gmail.com
}

\section{Article Info \\ Article history: \\ Received: March 11, 2020 \\ Accepted: March 29, 2020 \\ Published: March 30, 2020}

Keywords:
21st-century learning
Argumentation
Class assessment strategy
Creative thinking
Critical thinking

\section{Keywords:}

21st-century learning

Critical thinking

\begin{abstract}
ABSTRAK
The purpose of this research is to reconstruct the class assessment to promote 21 st-century learning. The meaning of reconstructing class assessment is the advanced assessment that can realize the purpose of 21 st-century learning which is the ability of argumentation, critical, and creative thinking skills. The advanced assessment in this research used the model of Argument-Driven Inquiry (ADI). This research is a quasi-experimental study that uses a pre-test post-test non-equivalent control group design. The research population is 12th-grade students of senior high school on Bandar Lampung. Based on data analysis, it was revealed that the classroom assessment strategy with continuous assessment using the ADI model can be used as a reference to be able to practice 21 stcentury life skills including argumentation, critical thinking, and creative skills.
\end{abstract}

\begin{tabular}{|c|c|}
\hline \multicolumn{2}{|c|}{$\begin{array}{l}\text { REKONSTRUKSI STRATEGI PENILAIAN KELAS: } \\
\text { MEMPROMOSIKAN PEMBELAJARAN ABAD } 21\end{array}$} \\
\hline & ABSTRAK \\
\hline $\begin{array}{l}\text { Kata Kunci: } \\
\text { Pembelajaran abad } 21 \\
\text { Argumentasi } \\
\text { Strategi penilaian kelas } \\
\text { Berpikir kreatif } \\
\text { Berpikir kritis }\end{array}$ & $\begin{array}{l}\text { Tujuan penelitian ini adalah merekonstruksi strategi penilaian kelas } \\
\text { untuk mempromosikan pembelajaran abad } 21 \text {. Rekonstruksi } \\
\text { strategi penilaian kelas yang dimaksud adalah penilaian } \\
\text { berkelanjutan yang mampu mewujudkan tujuan pembelajaran abad } \\
21 \text { diantaranya dapat melatih kemampuan argumentasi, } \\
\text { keterampilan berfikir kritis dan keterampilan berfikir kreatif siswa. } \\
\text { Penilaian berkelanjutan dalam penelitian ini menggunakan model } \\
\text { Argument-Driven Inquiry (ADI). Penelitian ini adalah penelitian } \\
\text { eksperimental semu, yang menggunakan desain kelompok kontrol } \\
\text { pre-test post-test nonequivalent. Populasi penelitian adalah siswa } \\
\text { SMA kelas XII Kota Bandar Lampung. Berdasarkan analisis data } \\
\text { terungkap bahwa strategi penilaian kelas dengan penilaian } \\
\text { berkelanjutan menggunakan model ADI sangat diperlukan untuk } \\
\text { dapat melatih kecakapan hidup abad 21. Berdasarkan analisis data } \\
\text { terungkap bahwa strategi penilaian kelas dengan penilaian } \\
\text { berkelanjutan menggunakan model ADI dapat dijadikan sebagai } \\
\text { salah satu rujukan untuk dapat melatih kecakapan hidup abad } 21 \\
\text { diantaranya keterampilan argumentasi, berfikir kritis, dan kreatif. }\end{array}$ \\
\hline
\end{tabular}




\section{INTRODUCTION}

Natural science learning should be done scientifically (scientific inquiry) to foster the ability to think, work, be scientific, and communicate it as an important aspect of life skills[1]. Severalaspectsof 21 st-century skills must be mastered by students is critical thinking[2]. Argument-Driven Inquiry (ADI) Model is one of the models to train critical thinking skills. ADI model is a model designed to plan the purpose of the class activities as an effort to develop, understand, or evaluation of the scientific explanation of a world phenomenon or a breakthrough of problem. [3] Besides that. ADI based learning can upgrade the inquiry skills and understanding of science [4]. The implementation of the Adi model uses 8 stages as shown in Table 1.

Table 1. Argument-Driven Inquiry Model Stage

\begin{tabular}{ll} 
& \multicolumn{1}{c}{ Argument-Driven Inquiry Stage } \\
\hline Stage 1: & Task Identification \\
Stage 2: & Data Collection \\
Stage 3: & Production of tentative Arguments \\
Stage 4: & Argumentation Session \\
Stage 5: & Preparation of a Written Investigation Report \\
Stage 6: & Report Review \\
Stage 7: & Revision Based on Review Result \\
Stage 8: & Reflective Discussion \\
\hline
\end{tabular}

Based on the description of several experts, it can be said that scientific inquiry needs to be empowered better graduates. It can fulfill $21^{\text {st }}$-century requirements. One solution that can be used is the ADI model.

The success of learning can't be separated from the assessment strategy. Because of that, class assessments applied to learn process should support the teaching-learning process [5]. Teacher assessments are considered an important factor to improve students' learning [6] [7] The teacher needs to self-reflect their ability to improve and how they assess the practices that give the impact public, institution, and individual [8]. So, the teacher has an important role in conducting a class assessment and they need to reconstruct the strategy of assessment hey have done all this time. Learning in the $21^{s t}$-century forced the teacher to innovate the assessment strategy used to support their teaching process.

Class assessments are designed to explore information about students' learning activities and experiences. Feedback received by students is the result of their work to improve further learning in a broader scope [9]. Professional development in the field of assessment must be prepared by the teacher[10]. The teacher's understanding of class assessment is very much needed, given its existence and the importance of a more inherent and incidental form of assessment [8], [11], [12]. Therefore, a teacher should be able to

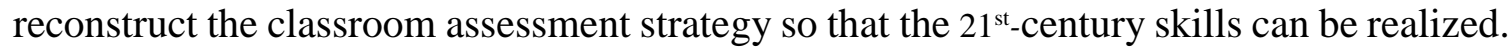

In previous studies, classroom assessment can improve students' critical thinking skills but needs to be integrated with interactive learning, teacher's ability, and student's ability in the learning process for solving problems[13] [14]. Regarding the $21^{\text {st }}$-century skill, previous research has developed assessment instruments that can be used as class assessments, it shows that the instruments can enhance critical abilities [15] creativethinking abilities [16], as well as the ability of argumentation [17]. However, there are no assessment instruments available that can measure the ability of argumentation, critical thinking, and creativity in an integrated manner.

Continuous assessment is a process to prepare students so that they can provide a clear response to know the extent of students' understanding and aim to help improve students' performance at subsequent meetings [18]. Also, the classroom assessment 
strategy undertaken by the teacher should be an ongoing assessment conducted during the learning process. Continuous assessment is a blend of students' thought processes and teacher feedback needed to improve student understanding of a particular topic or concept. Feedback is one factor that is very influential in the success of the learning process and achievement [19]. Giving the feedback both reflectively and constructively will improve the quality of student learning [20]. Also, active and dynamic learning is very dependent on feedback [21].

An implementation that considers questions that require thinking to measure the level of thought and not only measure students' work, but also student work processes is needed [22] $21^{\text {st }}$-century learning emphasizes the 4C capabilities of Communication, Collaboration, Critical-Thinking, and Creative Thinking [23]. A teacher should be in the learning process that applies classroom assessment strategies that can foster the ability of argumentation, critical thinking skills, and creative thinking.

\subsection{Argumentation skills}

Argumentation is the process of gathering various comments needed to build an opinion[24]. There are several components of argumentations namely: claim, evidence, warrant, backing, qualifier, and rebuttal [25].The quality of argumentation divided into several levels with characteristic criteria [24] in Table 2.

Table 2. Quality Analysis frame Work of Argumentations

\begin{tabular}{cl}
\hline Tiers (Level) & \multicolumn{1}{c}{ Characteristics } \\
\hline Level 1 & $\begin{array}{l}\text { Argumentation consists of in the form of a simple claim with the } \\
\text { opposite claim (counterclaim). }\end{array}$ \\
Level 2 & $\begin{array}{l}\text { Argumentation consists of arguments in the form of claim with } \\
\text { counterclaim accompanied by data, (warrant) or support (backing) } \\
\text { but doesn't contain refutation (rebuttal). }\end{array}$ \\
Level 3 & $\begin{array}{l}\text { Argumentation consists of arguments with claim roles or } \\
\text { counterclaims which accompanied by data, guarantee (warrant) or } \\
\text { support (backing) with once in a while (weak rebuttal). } \\
\text { Argumentation consists of arguments with the claim with one who } \\
\text { can identification clearly and precisely. One argument can have the } \\
\text { refutation claim or counterclaim. } \\
\text { Argumentation consists of arguments wide (extended but remain } \\
\text { Level 5 }\end{array}$ \\
&
\end{tabular}

\subsection{Critical Thinking Skills}

$21^{\text {st }}$-century learning requires teachers to always develop the learning process in class. This is certainly very much related to the expertise of teachers in developing strategies of class assessment. The goals of life skills in the $21^{\text {st }}$-century are life and career skills, skills in technology, media, and information, as well as critical thinking skills, and innovation[26][27] [28]. Critical thinking is reflective thinking taken on the pattern of decision making about what must be agreed and must be done [29]. There are five indicators of critical thinking are namely: (1) providing simple explanations (elementary clarification), focusing on questions, analyzing, asking, and answering questions that are needed or challenged; (2) building basic skills (basic support) considering the credibility of the source and making observational considerations; (3) concludes (concludes) arranges compiles and considers deductions, arranges decisions and considers results; (4) provide further clarification (advanced clarification ) including requirements, considerations, and approvals; (5) Set the Strategies and tactics determine how to act and support others [29].

Indonesian Journal of Science and Mathematics Education (IJ S M E) $\mid 29$ 


\subsection{Creative Thinking Skills}

The challenges of $21^{\text {st }}$-century learning include thinking creatively to solve a problem[30]. There is a relationship between the ability to think creatively with student learning achievement[31] Previous research states that the use of assessment instruments for learning science can improve students' critical thinking and creative thinking skills [32].

Creative thinking criteria are fluency, flexibility, and novelty. Fluency refers to the ability to produce diverse and correct answers from problems given. Flexibility refers to students' ability to give diverse ways to solve problems. Novelty refers to students' ability to answer the problem with the diverse and correct answer or one answer that is not usually done by their level [33]. Creative thinking level is the identification on several levels, which is level 0 (Not creative) where the student can't solve the problem with one or more solutions and can't represent other ways to solves them. Level 1 (Less Creative) is when a student can solve the problem with more than one way but can't represent other ways. Level 2 (Quite creative) is when a student can solve the problem with one real solution but not completely appropriate or not flexible. level 3 (Creative) student can solve the problem with more than one solution but not represent another way to solve it. And level 4 (Very creative) students can solve the problem with more than one solution and able to represent other ways to solve it [34].

\section{METHOD}

This research method used is a quasi-experimental study with a non-equivalent pretest post-test control group design. The method the researcher uses is presented in the following chart.

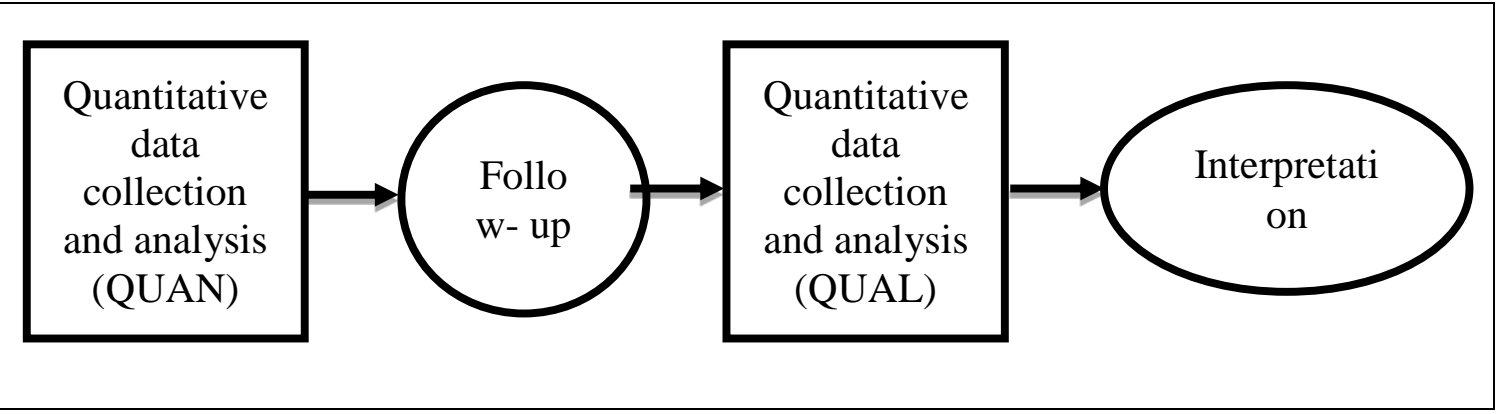

Figure 1. The Quasi-Experimental Design

The study population was the twelfth-grade high school students in Bandar Lampung City during the first semester of 2019/2020 academic. The population consisted of 127 students. This research used two classes as samples determined through a purposive sampling technique. The two selected classes were then divided into the experimental class and the control class. The continuous assessment strategy with the ADI model was applied in the experimental class while the learning approach commonly used by teachers (conventional approaches) was used in the control class

$\mathrm{N}$-gain was employed to analyze the learning outcomes data. N-Gain Analysis shows the score differences between the Experiment and control classes. [35]. The following is the N-Gain formula.

$$
\text { N-Gain }(\mathrm{g})=\frac{\text { Post }- \text { test score }- \text { Pretest score }}{\text { Ideal Max score-Pretest score }}
$$


Table 3. Interpretation Criteria of N-Gain

\begin{tabular}{cc}
\hline $\mathbf{N}-$ Gain & Interpretation Criteria \\
\hline $\mathrm{N}$-gain $>0,7$ & High \\
$0,3 \leq \mathrm{N}$-gain $\leq 0,7$ & Medium \\
$\mathrm{N}$-gain $<0,3$ & Low \\
\hline
\end{tabular}

\section{RESULT AND DISCUSSION}

\subsection{Argumentation ability}

The results showed that the argumentation ability of the control class and experimental class students before being treated (pretest) was at level 1 argumentation. At level 1 argumentation, the students were only able to make claims without the support of data. This level, the argument is only built on claims, claims are conclusions or opinions of students based on the knowledge they have [36]. Furthermore, the experimental class was treated by using continuous assessment with the ADI model, whereas in the control class using a conventional model. Based on the results of data processing, it was found that with the ADI model continuous assessment learning, the argumentation ability of students in the experimental class was at level 1, namely claims, but an increase in the percentage of students at the claim level was $16.3 \%$ (pre-ex) to $41.7 \%$ (post- ex), at level 2, namely claims with data, there are $25.7 \%$ (post-ex) from before learning $0 \%$ (pre-ex). Whereas in the control class with conventional learning found students' argumentation ability remained at level 1, before learning $15.7 \%$ (pre-ctrl) and after learning took place the ability of argumentation became $38.3 \%$ (post-ctrl). Details of the percentage of indicators of control class and experimentation argumentation skills are shown in Figure 2.

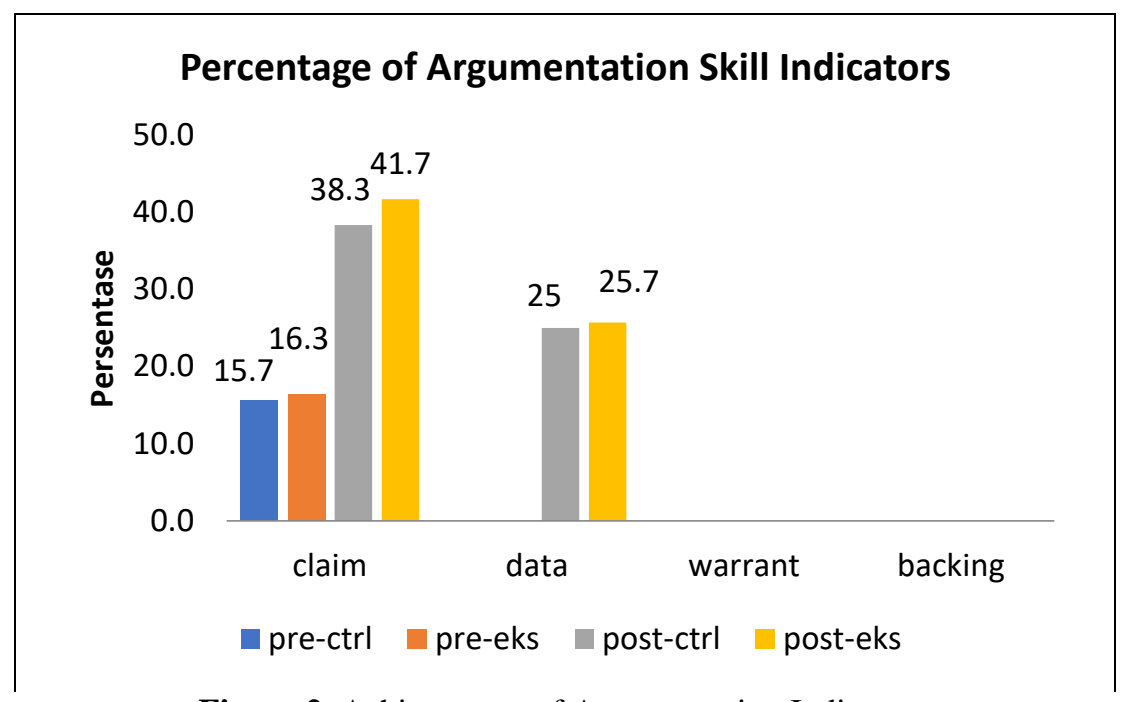

Figure 2. Achievement of Argumentation Indicators

Figure 2 shows the percentage of students' ability in low classification. The act does to train the argumentation ability of students are apply strategies advanced assessment with the Argument-Driven-Inquiry model. Implementation of the Argument-Driven Inquiry is an effective model for including the academic achievement and processes science skills [37]. The ADI learning model is a learning model that is designed to change conventional learning to give students learning opportunities in reflective scientific inquiry to then be able to develop students' critical thinking and argumentation skills [38] [39].

From Figure 2 it also appears to be an increase in students' argumentation skills by 25.4\%. Learning by using an ongoing assessment strategy with this ADI model has syntax including task identification, data collection, argumentative production, interactive 
argument sessions and preparation of written inquiry reports. Each syntax or learning stage has prepared a series of assessment strategies, both cognitive assessment through oral or written tests, psychomotor assessments through performance or portfolios and affective assessments through daily journals. The application of the assessment strategy during the learning process is expected to be able to help a full assessment of the skills and experience of the student.

\subsection{Critical thinking skills}

Research achievement relatively states that students' critical thinking achievement in control and experimental class before and after given the treatments (Pretest) and (Posttest) shown by Tables 4 and 5 .

Table 4. Achievement of Class control Critical thinking skills

\begin{tabular}{ccc}
\hline Critical Thinking Skills (CTS) & Pretest (\%) & Post-test (\%) \\
\hline Elementary Clarification & 52,1 & 56,9 \\
Basic Support & 25 & 39,2 \\
Inference & 11,7 & 38 \\
Advance Clarification & 10 & 19,2 \\
strategy and tactics & 0 & 9,3 \\
\hline
\end{tabular}

Table 5. Achievement of Experiment Class Critical Thinking Skills

\begin{tabular}{lcc}
\hline \multicolumn{1}{c}{ Critical Thinking Skills (CTS) } & Pretest (\%) & Post-test (\%) \\
\hline Elementary clarification & 51,7 & 59,6 \\
Basic support & 25 & 44,2 \\
Inference & 14,2 & 41,7 \\
Advance clarification & 13 & 20,8 \\
Strategy and tactics & 0 & 16,7 \\
\hline
\end{tabular}

Table 4 shows that students' critical thinking skills in the control class, both pre-test and post-test, are used well when solving problems with indicators giving a simple explanation (elementary clarification). Other information found that critical thinking skills build the basic skills (basic support), inference (inference) and provide further clarification (advance clarification), have not been achieved properly, only in the range of under $40 \%$ and skills that are not yet possessed by students is to arrange strategies and tactics (strategy and tactics) occur in conditions before learning (pre-test) and after the learning process (pre-test) these skills begin to appear even though relatively low at $9.3 \%$.

Table 5 shows that students 'critical thinking skills of the experimental class show that students' critical thinking skills in the experimental class show information that is not much different either pre-test or post-test are used properly when solving questions with indicators giving a simple explanation (elementary clarification). In the initial conditions, the indicator gave a simple explanation of the experimental class smaller than the experimental class, but after the learning process by applying continuous assessment using the ADI model, an increase in the indicator gave a simple explanation of 59.6\%. Other information is also found that critical thinking skills build basic skills (basic support), inference (inference) and provide further clarification (advance clarification), have not been well achieved, only in the range below $40 \%$ and skills that are not at all possessed by students are formulating strategies and tactics (strategy and tactics) this occurs in conditions before learning (pre-test) and after the learning process (pre-test) these skills begin to appear even though relatively low at $16.7 \%$. 
Students' critical thinking skills of basic level can be enough provision that to resolving the physics material problem grade 12 senior high school at Bandar Lampung City. On the indicator (finished, make further explanation) students still need to be improved. The results of this study also reveal an increase in mastery of physical material between before and after learning is carried out, which is expressed by the normalized gain (N-gain). Data received by $\mathrm{N}-\mathrm{Gain}$ can be seen in Table 6 .

Table. 6. Achievement Presentation of Students' N-Gain

\begin{tabular}{ccc}
\hline Interpretation Criteria & Control Class & Experimental Class \\
\hline High & $0 \%$ & $0 \%$ \\
Medium & $36 \%$ & $80 \%$ \\
Low & $64 \%$ & $20 \%$ \\
\hline
\end{tabular}

Based on the N-Gain achievement data results in table 5, it can be seen that the percentage of students who obtained critical criterion thinking skills was in the experimental class higher than the control class, so it can be said that the increase in critical thinking skills was higher in the experimental class. The findings in the study based on the data in table 5, it is known that the critical thinking skills of students in Bandar Lampung city high school have not yet reached the high criteria.

\subsection{Creative thinking skills}

Research achievement relatively states that students' critical thinking achievement in control and experimental class before and after given the treatments (Pre-test) and (Post-test) shown by Tables 7 and 8 .

Table 7. Achievement of Control class Creative Thinking Skills

\begin{tabular}{ccc}
\hline Creative Thinking Skills (CTS) & Pretest (\%) & Posttest (\%) \\
\hline Fluency & 54,2 & 56,3 \\
Flexibility & 18,8 & 30,2 \\
Original & 18,8 & 29,2 \\
Elaboration & 6,3 & 15 \\
\hline
\end{tabular}

Table 8. Achievement of Experimental class Creative thinking skills

\begin{tabular}{ccc}
\hline Creative thinking skills (CTS) & Pretest (\%) & Posttest (\%) \\
\hline Fluency & 52,1 & 59,2 \\
Flexibility & 17,7 & 41,7 \\
Orginal & 16,3 & 33,3 \\
Elaboration & 8,3 & 16,7 \\
\hline
\end{tabular}

The final capability data obtained in this study is the data after it is given treatment. Test results have shown an increase in the average final test that is higher than before. The average value of the experimental class was 60.4 and the control class was 45.4 . Final Test students in both classes experienced an increase from the initial test. This can be seen from the average value obtained by the experimental class is higher than the control class. This is due to the advanced assessment strategy with the ADI model.

Comparison of the improvement of the experimental class and the control class shows that the initial abilities of the two classes are not much different, even the control class has the highest value greater than the experimental class. After being given treatment both classes experienced an increase, but the experimental class increased higher than the control class. 
The final ability in both classes increased, but the increase in the experimental class was higher than the control class. This is because the treatment is given to the experimental class and the control class is different. In the experimental class applied continuous assessment with the ADI model, while the control class uses conventional learning models. Where in the ADI learning model students are activated directly through the stages, namely starting from the identification of tasks, collecting data in the classroom or laboratory, the argumentative production stage, namely students constructing arguments in groups, interactive argument session stages namely students presenting the results of the discussion to then given input or responses by other groups and the stages of compiling reports on group work results.

\section{CONCLUSSION}

Based on data analysis, it was revealed that the classroom assessment strategy with continuous assessment using the ADI model can be used as a reference to be able to practice $21^{\text {st }}$-century life skills including argumentation, critical thinking, and creative skills.

\section{REFERENCES}

[1] BNSP. (2006). Panduan PenyusunanKurikulum Tingkat Satuan Pendidikan Jenjang Pendidikan Dasar dan Menengah Badan StandarNasional Pendidikan.

[2] Hubert, S. Latifah, A. Anugrah, A. Saregar, Misbah, and K. Jermsittiparsert, (2019) "Approaching Problem-Solving Skills of Momentum and Impulse Phenomena Using Context and Problem-Based Learning," Eur. J. Educ. Res., vol. 8, no. 4, p. 1217

[3] Sampson, V., \& Gleim, L. (2009). in Biology ARTICLE Argument-Driven Inquiry To Promote $\mathrm{AB}$ ? of the Understanding Important Concepts \& Practices O ?... students need The American Argument Driven. The American Biology Teacher, 71(8),465-472.

[4] Sampson, V., Enderle, P., Grooms, J., \& Southerland, S.A. (2012). Using laboratory activities that emphasize argumentation and argument to help high school students learn how to engage in scientific inquiry and understand the nature of scientific inquiry. Paper presented at the annual international conference of the Nat. In The Annual International Conference of the National Association for Research in Science Teaching (NARST) Indianapolis, ID (p. 11).

[5] Heritage, M. (2010). Formative Assessment and Next-Generation Assessment Systems: Are We Losing an Opportunity? Washington, DC: Council of Chief State School Officers.

[6] T. Rahayu and K. Osman, (2019) "Knowledge Level And Self-Confidence On The Computational Thinking Skills Among Science Teacher Candidates," Jurna Ilm. Pendidik. Fis. Al-Biruni, vol. 8, no. 1, pp. 117-126

[7] Hattie, J. (2009). Visible Learning: A Synthesis of Over 800 Meta-Analyses Relating to Achievement. Hoboken: Taylor \& Francis.

[8] Fulcher, G. (2012). Assessment literacy for the language classroom. Language Assessment Quarterly, 9(2), 113-132.

[9] Parahat, R., Rosidin, U., Abdurrahman. 2013. Analisis Hasil Belajar Fisika Menggunakan On going Assessment Teknik IF-AT. Jurnal Pembelajaran Fisika.

[10] Tsagari, D. (2011). Investigating the 'assessment literacy' of EFL state school teachers in Greece. In D. Tsagari\& I. Csépes (Eds.), Classroom-based language assessment (pp.169-190). Frankfurt am Main: Peter Lang. 
[11] Purpura, J. Liu, H., Tsutagawa, F.S, Woodson, S. (2014). Tracking the Development of Learning Outcomes in a Learning-Oriented Approach to Classroom-Based L2 Assessment. Paper presented at the Language Testing Research Colloquium (June, Amsterdam).

[12] Torrance, H. \&. Pryor, J. (1998). Investigating Formative Assessment: Teaching, learning and assessment in the classroom. Buckingham: Open University

[13] Wartono, J. Takaria, J. R. Batlolona, S. Gruscher, M. N. Hudha, and Y Jayanti, "Inquiry-Discovery Empowering High OrderThinking Skills And Scientific Literacy On Substance Pressure Topic,” Jurna Ilm. Pendidik. Fis. Al-Biruni, vol. 7, no. 2, p. 140, 2018.

[14] Angelo, T. 1995. Beginning the dialogue: thoughts on promoting critical thinking. Teaching of Psychology. Vol 2 (1).

[15] Setiawan, A., Rosidin, U., \& Abdurrahman. 2019. The Effectiveness of Ongoing Assessment on Physics Learning Improving Students Critical Thinking Skills. International Education Research. Vol 2(2).

[16] Rosidin, U., Distrik, I. W., \&Herlina, K. 2018. The Development of Assessment for learning Science to Improve Student's Critical and Creative Thinking Skills. International Conference on Educational Assessment and Policy. Vol. 1 (1). 61-67.

[17] Viyanti, Cari, Sunarno, W., \&Prasetyo, Z. K. 2016. AnalisisArgumentasiMateriTerapung dan Tenggelam. Jurnal Pendidikan Fisika dan Keguruan. Vol 2 (2).

[18] Joslin, Cara. 2010. Teaching for Understanding: Ongoing Assessment. Harvard University Graduet School of Education and Project Hero.

[19] Heitink, M. C., Van der Kleij, F. M., Veldkamp, B. P., Schildkamp, K., \& Kippers, W. B. (2016). A systematic review of prerequisites for implementing assessment for learning in classroom practice. Educational Research Review, 17, 50-62.

[20] Thomas, G., Martin, D., \& Pleasants, K. (2011). Using self and peer-assessment to enhance students' future learning in higher education. Journal of University Teaching \& Learning Practice, 8(1), 5 .

[21] Abdurrahman, S. A., \&Umam, R. (2018). The Effect Of Feedback As Soft Scaffolding On Ongoing Assessment Toward The Quantum Physics Concept Mastery Of The Prospective Physics Teachers. Jurnal Pendidikan IPA Indonesia, 7(1), 16-22.

[22] Kearney, S. (2013). Improving engagement: the use of 'Authentic self-and peer- assessment for learning' to enhance the student learning experience. Assessment \& Evaluation in Higher Education, 38(7), 875-891.

[23] Partnership for 21st Century Skills. (2006). Framework for 21st century learning. Retrieved.

[24] Simon Shirley, Sibel Erduranb, dan Jonathan Osborne.2006. Learning to Teach Argumentation: Researchand Development in The Science Classroom International Journal of Science Education. 28 (2-3)235-260.

[25] Chan-Choong Foong dan Esther G. S. Daniel. 2010. Assessing Students' Arguments Made in SocioScientificContexts:The Considerations of Structural Complexity and The Depth of Content Knowledge. Procedia Social and Behavioral Sciences. 9. $1120-1127$

[26] Listiana, Abdurrahman, A. Suyatna, and P. Nuangchalerm, "The Effect Of Newtonian Dynamics STEM-Integrated Learning Strategy To Increase Scientific Literaci Of Senior High School Students.," Jurna Ilm. Pendidik. Fis. Al-Biruni, vol. 8, no. 1, pp. 43-52, 2019.

[27] Z. S. Pamungkas, N. S. Aminah, and F. N. Rosyid, "Students Crictical Thinking Skill in Solving Scientific Literacy using A Metacognitive Test Based On Scientific 
Literacy,” J. Ilm. Pendidik. Fis. Al-Biruni, vol. 7, no. 2, p. 161, 2018.

[28] Ledward, BC, \& Hirata. (2011). An overview of $21^{\text {st }}$ century skills. Summary of $21^{\text {st }}$ Century Skills for Students and Teachers, by Pasific Policy Research Center. Honolulu: Kamehame Schools-Research and Evaluation.

[29] Ennis, R. H. 2011. The Nature of Criticall Thinking: An Outline of Criticall Thinking Disposition and Abilities. Chicago: University of Illinois.

[30] A. Malik, Y. Nuraeni, A. Samsudin, and Sutarno, "Creative Thinking Skills of Students On Harmonics Vibration Using Models Student Facilitator And Explaining (SFAE)," J. Ilm. Pendidik. Fis. Al-Biruni, vol. 8, no. 1, pp. 77-88, 2019.

[31] Wang, A. Y. 2011. Contexts of Creative Thinking: A Comparison on Creative Performance of Student Teachers in Taiwan and the United States. Journal of International and Cross-Cultural Studies, Vol. 2, (1). 56-68.

[32] Rosidin, U., Distrik, I. W., \&Herlina, K. 2018. The Development of assessment for learning Science to Improve Student's Critical and Creative Thinking Skills. International Conference on Educational Assessment and Policy. Vol. 1 (1). 61-67.

[33] Silver, E. A. 1997. Fostering Creativity Through Instruction Rich In Mathematical Problem Solving and Problem Posing. ZDM International Reviews on Mathematical Education, 29(3).

[34] Siswono, T. 2011. Level of Student's Creative Thinking in Clasroom Mathematics. Educational Research and Review, 6(7). ISSN 1990-3839. Hal. 548 - 553.

[35] Hake, R. R., Relationship of Individual Student Normalized Learning Gains in Mechanics with Gender, High-School Physics, and Pretest Scores on Mathematics and Spatial Visualization. Physics Education Research Conference.; Boise, Idaho, 2002.

[36] C. V. Aufschnaiter et al., "Arguing ToLearn and Learning to Argue: CaseStudies of How Students' ArgumentationRelates to Their Scientific Knowledge,Journal of Research In Science Teachingvol. 45, no. 1, pp. 1-131, 2008.

[37] Demircioglu, T., \&Ucar, S. (2015). Investigating the effect of argument-driven inquiry in laboratoryinstruction. Educational Science: Theory \&Practice, 15(1), 267283.

[38] Sampson, V., Grooms, J., \& Walker, J. P. (2010). Argument-Driven Inquiry as a way to help students learn how to participate in scientific argumentation and craft written arguments: An exploratory study. Science Education, 95(2), 217-257.

[39] Kadayifci, H., Atasoy, B., \&Akkus, H. (2012). The Correlation Between the Flaws Students Define in an Argument and their Creative and Critical Thinking Abilities. Procedia - Social and Behavioral Sciences, 47, 802-806. 